\title{
RHINOLOGY
}

\section{Definition and management of invasive fungal rhinosinusitis: a single-centre retrospective study}

\author{
Definizione e gestione della rinosinusite fungina invasiva: uno studio retrospettivo \\ monocentrico
}

\author{
Gian Luca Fadda', Federica Martino ${ }^{1,2}$, Giacomo Andreani³ ${ }^{3}$ Giovanni Succo ${ }^{4,5}$, Maurizio Catalani6, \\ Stefano Di Girolamo², Giovanni Cavallo ${ }^{1}$ \\ ${ }^{1}$ Department of Otolaryngology, San Luigi Gonzaga Hospital, University of Turin, Orbassano, Turin, Italy; ${ }^{2}$ Otorhinolaryngology \\ Unit, Department of Clinical Sciences and Translational Medicine, Tor Vergata University, Rome, Italy; ${ }^{3}$ Department of Clinical and \\ Biological Sciences, San Luigi Gonzaga Hospital, University of Turin, Orbassano, Turin, Italy; ${ }^{4}$ FPO IRCCS, Head \& Neck Oncology \\ Unit, Candiolo Cancer Institute, Turin, Italy; ${ }^{5}$ Oncology Dept. University of Turin, Italy; ${ }^{6}$ Department of Otolaryngology, Humanitas \\ Cellini, Turin, Italy
}

\section{SUMMARY}

Objectives. The purpose of this study was to correlate acute invasive fungal rhinosinusitis (AIFRS) and chronic invasive fungal rhinosinusitis with underlying diseases, aetiological microorganisms, clinical symptoms, radiological findings, and surgical and medical treatment to determine the subset of patients who require more accurate diagnostic investigation and to prevent irreversible complications.

Methods. This retrospective monocentric study included 17 patients who underwent endoscopic sinus surgery evaluated by paranasal computed tomography and magnetic resonance imaging. Age, sex and symptoms, and location of the invasive fungal infection and the causative fungus were analysed.

Results. In total, 4 patients were affected by the AIFRS form, and 13 by the chronic form. Diabetes mellitus was reported in $41.17 \%$ of cases, and haematological diseases in $23.52 \%$. The maxillary sinuses were involved in $47.05 \%$ of cases and sphenoidal sinuses in $52.94 \%$; Aspergillus fumigatus was the fungus in $76.47 \%$ of cases, and Zygomycetes in $23.53 \%$. Conclusions. An understanding of the different types of fungal sinusitis and knowledge of their features play a crucial role in reaching prompt diagnosis and initiation of appropriate therapy, which is essential to avoid a protracted or fatal outcome.

KEY WORDS: Aspergillus, Mucormycosis, invasive fungal rhinosinusitis, isavuconazole, liposomal amphotericin B

\section{RIASSUNTO}

Obiettivi. Nonostante i progressi in termini di trattamento, la mortalità nei casi di rinosinusite fungina invasiva rimane elevata, pertanto, scopo dello studio è stato correlare le forme acute invasive e quelle croniche con patologie concomitanti, agenti eziologici, $i$ sintomi clinici, radiologia e trattamento, al fine di identificare e trattare i pazienti con prognosi peggiore.

Metodi. Il seguente studio retrospettivo monocentrico ha incluso 17 pazienti sottoposti a chirurgia endoscopica sinusale, valutati mediante TC e RM e analizzati per età, sesso, sintomi, sede dell'infezione fungina invasiva e microrganismi eziologici.

Risultati. 4 pazienti sono risultati affetti dalla forma invasiva acuta, 13 pazienti dalla forma cronica. Il diabete mellito è stato riscontrato nel 41,17\% dei casi, malattie ematologiche nel 23,52\%. I seni mascellari sono risultati coinvolti nel 47,05\% dei pazienti e seni sfenoidali nel 52,94\%; Aspergillus ha provocato il 76,47\% dei casi, Zigomiceti il 23,53\%.

Conclusioni. Un'adeguata comprensione dei diversi tipi di sinusite fungina e la conoscenza delle loro caratteristiche svolgono un ruolo cruciale ai fini di una diagnosi precoce e l'avvio di una terapia appropriata con lo scopo di ridurne la mortalità.

PAROLE CHIAVE: Aspergillus, Mucormycosis, rinosinusite fungina invasiva, Isavuconazolo, amfotericina B liposomiale
Received: May 12, 2020

Accepted: September 14, 2020

\section{Correspondence}

Gian Luca Fadda

Department of Otolaryngology, San Luigi Gonzaga Hospital, Regione Gonzole 10, 10043 Orbassano, Turin, Italy

Tel. +390119026463

E-mail: dott.fadda@gmail.com

Funding

None.

Conflict of interest

The Authors declare no conflict of interest.

How to cite this article: Fadda GL, Martino F, Andreani G, et al. Definition and management of invasive fungal rhinosinusitis: a single-centre retrospective study. Acta Otorhinolaryngol Ital 2021;41:43-50. https://doi. org/10.14639/0392-100X-N0848

() Società Italiana di Otorinolaringoiatria e Chirurgia Cervico-Facciale

\section{(c) (1) $(2)$}

This is an open access article distributed in accordance with the CC-BY-NC-ND (Creative Commons Attribution-NonCommercial-NoDerivatives 4.0 International) license. The article can be used by giving appropriate credit and mentioning the license, but only for non-commercial purposes and only in the original version. For further information: https:// creativecommons.org/licenses/by-nc-nd/4.0/deed.en 


\section{Introduction}

The concept of invasiveness for a fungal infection refers to the potential for fungal hyphae to invade epithelial tissue with potential neural and vascular involvement ${ }^{1,2}$. We can categorise invasive fungal rhinosinusitis (IFRS) into three subgroups: acute invasive fungal rhinosinusitis (AIFRS), chronic invasive fungal rhinosinusitis and chronic granulomatous invasive fungal rhinosinusitis ${ }^{3}$.

Invasive fungal rhinosinusitis (IFRS) generally occurs in immunocompromised patients, i.e. those with haematological malignancies or undergoing chemotherapy or allogeneic haematopoietic transplantation, patients with AIDS, and in poorly controlled diabetic patients undergoing immunosuppressive therapy ${ }^{4}$.

Acute invasive fungal rhinosinusitis (AIFRS) is defined by a time course of less than 4 weeks' duration, with predominant vascular invasion. The infection results from rapid spread of fungi from the paranasal sinuses to the adjacent orbits and central nervous system with hyphal invasion of blood vessels, vasculitis with thrombosis, haemorrhage, tissue infarction and acute neutrophilic infiltrates with a necrotising pathological reaction ${ }^{5}$.

Chronic IFRS is an indolent infection with a slow destructive process that most commonly affects the ethmoid and sphenoid sinuses, but may involve any paranasal sinus ${ }^{6,7}$.

Despite improvements in both medical and surgical therapies, the mortality of patients with IFRS remains high (50$80 \%$ ) mostly due to invasion of the orbit and intracranial cavity ${ }^{8,9}$; in fact, early and accurate diagnosis is essential because prognosis is often governed by the rapid initiation of antifungal therapy and/or surgical debridement ${ }^{10}$.

Therefore, the purpose of this article was to correlate AIFRS and chronic indolent IFRS with underlying diseases, aetiological microorganisms, clinical symptoms, radiological findings, and surgical and medical treatment.

The study aimed to aid clinicians in the decision-making process by systematically assembling previously published evidence and new updates on medical treatment, and to consider the possibility of identifying a subset of patients who require more accurate diagnostic investigation to prevent irreversible complications.

\section{Materials and methods}

This single-centre retrospective study included 17 patients affected by IFRS who underwent endoscopic sinus surgery (ESS) at the ENT Department in San Luigi Gonzaga Hospital, Turin, Italy between January 2016 and January 2020. For inclusion, patients were required to have histopathologically confirmed IFRS, defined by the evidence of fungal hyphae in the mucosa of the affected sinus. Patients aged
$<18$ years, those who had previously received nasal surgery or who had been diagnosed with non-invasive fungal rhinosinusitis were excluded.

Patients' records were analysed retrospectively for presenting symptoms, underlying diseases, causative microorganisms, radiological findings, and medical and surgical treatment. All enrolled patients were evaluated preoperatively with paranasal computed tomography (CT) and magnetic resonance imaging (MRI). In addition, age, sex and symptoms as well as the location of the invasive fungal infection and the causative fungus were analysed for each patient.

Tissue samples were collected for both microbiological and histopathological examination to provide a definitive diagnosis. A mucosal biopsy sample was also collected from the sinus wall and evaluated histologically. A swab sample was taken from purulent sinus secretions and sent to the microbiology laboratory for bacterial culture under both aerobic and anaerobic conditions. When feasible, galactomannan and beta-D-glucan were tested in blood samples. Galactomannan (GM) is a molecule that is present in the cellular walls of Aspergillus species and can be secreted extracellularly. Several studies have shown that the determination of GM is beneficial for diagnosis and, together with 1,3-beta-D-glucan (BDG) antigens, can improve the sensitivity of invasive aspergillosis diagnosis ${ }^{11}$.

All patients underwent debridement through endoscopic sinus surgery (ESS) under general anaesthesia as the first choice to remove the entire lesion in the sinus using rigid endoscopes (Karl Storz Endoskope, Germany) with a diameter of $4 \mathrm{~mm}$ and viewing angles of $0^{\circ}, 45^{\circ}$ and $70^{\circ}$. After surgery, specific medical antifungal treatment was initiated as prescribed by an infectious disease specialist, and in the case of positive cultures indicating bacterial coinfection, the type of antibiotic therapy was determined by antibiogram results. All patients were prospectively followed through endoscopic monitoring performed at intervals of $15,30,60,90$ days, 6 months and 1 year after surgery. Using a rigid endoscope, secretions and crusts were removed at the outpatient department and postoperative home treatment included nasal saline irrigation twice a day for at least 3 months. Therapeutic success was clinically and endoscopically defined as patients who were asymptomatic at 6 months after completing the antifungal therapy. Follow-up with MRI was only performed when recurrence was suspected. No patient was lost during the follow-up period. This study was in line with the guidelines of the Helsinki Declaration for ethical consideration. Accordingly, written informed consent was obtained from all patients. Categorical data are presented as frequencies. 


\section{Results}

The study included 17 patients ( 8 women and 9 men) affected by IFRS, diagnosed between January 2016 and January 2020. Their median age was 57 years, range: $31-82$ years, and the interquartile range (IQR) was $27 \pm 14.77$ years. In total, 4 patients were affected by the AIFRS form (Tab. I) and 13 patients had the chronic indolent form (Tab. II).

The most common underlying disease was diabetes mellitus reported in 7 cases $(41.17 \%)$ followed by haematological diseases in 4 cases $(23.52 \%)$ : myelodysplastic syndrome $(\mathrm{n}=1)$, non-Hodgkin lymphoma $(\mathrm{n}=1)$ and acute myeloid leukaemia $(n=2)$. Furthermore, 5 patients $(29.41 \%)$ had neutropenia. An autoimmune condition, rheumatoid arthritis, was recognised in 1 case. Another cause of immunodeficiency was steroid therapy, found in 1 patient. Alveolar rhabdomyosarcoma together with chemoradiotherapy and neutropenia were observed in 1 patient. As reported in Tables I and II, several patients showed different associations of these underlying diseases, with different symptoms occurring simultaneously in the same patient.

Facial pain and headache were the most commonly reported presenting signs and symptoms in 12 (70.58\%) and $8(47.05 \%)$ patients, respectively; 6 patients had ocular diseases (35.29\%): diplopia was observed in 4 patients $(23.52 \%)$, proptosis in $3(17.64 \%)$ and bilateral amaurosis in 1 case $(5.88 \%)$. Cranial nerve palsy (VI) was present in 2 patients $(11.76 \%)$ and trigeminal neuralgia in 1 patient $(5.88 \%)$. The average time between the onset of symptoms to presentation in the emergency room and the beginning of the diagnostic process was about 2 days for AIFRS and 10 days for the chronic indolent form. No patient had received medical treatment at other healthcare facilities.

CT and MRI were used preoperatively to determine the extent of fungal invasion: $14(82.35 \%)$ patients had unilateral involvement of the paranasal sinuses and one of them $(5.88 \%)$ also showed the simultaneous involvement of two different sinuses, the maxillary and sphenoid sinus (\#4 Tab. II) on the right side. Three patients (17.64\%) had bilateral fungal invasion.

Our data also showed involvement of the maxillary sinuses in 8 patients $(47.05 \%)$ and of the sphenoid sinuses in 9 patients (52.94\%); there was simultaneous involvement of both paranasal sinuses in 1 patient $(5.88 \%)$. The principal radiologic findings with $\mathrm{CT}$ and MRI are summarised in Tables III and IV, respectively.

Five patients showed extra-sinus involvement of the fungal disease $(29.41 \%)$ : the cavernous sinus was the site of the most frequent dissemination being present in 5 patients ( $29.41 \%)$, followed by 2 cases $(11.76 \%)$ with intracranial involvement and 2 cases $(11.76 \%)$ with thrombosis of the internal carotid artery (ICA) $(11.76 \%)$. Ocular manifestations were also detected: orbital and optic nerve involvement $(\mathrm{n}=2,11.76 \%)$ and VI cranial nerve palsy $(\mathrm{n}=4$, $23.52 \%)$.

All patients underwent endoscopic debridement with endoscopic sinus surgery (ESS) under general anaesthesia, with complete removal of all necrotic tissue. No other surgical procedures were performed. The time from the patient's arrival at the hospital to ESS varied from less than 1 day to 70 days (median: 35 days, IQR: 57.5 days): all AIFRS patients underwent emergency ESS immediately. In the group

Table I. Clinical and radiological features of the 4 patients with AIFRS.

\begin{tabular}{|c|c|c|c|c|c|c|c|c|}
\hline $\begin{array}{l}\text { ID } \\
\text { sex, } \\
\text { age }\end{array}$ & $\begin{array}{l}\text { Underlying } \\
\text { diseases }\end{array}$ & $\begin{array}{c}\text { Presenting } \\
\text { symptoms and signs }\end{array}$ & $\begin{array}{l}\text { Sinuses } \\
\text { involved }\end{array}$ & $\begin{array}{c}\text { Extra } \\
\text { sinonasal sites }\end{array}$ & $\begin{array}{l}\text { Fungal } \\
\text { species }\end{array}$ & Microbiologic & $\begin{array}{l}\text { Antifungal } \\
\text { therapy }\end{array}$ & $F / U$ \\
\hline $\begin{array}{l}1 \\
M, 57\end{array}$ & $\begin{array}{l}\text { Acute myeloid } \\
\text { leukaemia, } \\
\text { Neutropenia }\end{array}$ & $\begin{array}{c}\text { Diplopia } \\
\text { cranial nerve palsy } \\
\text { (VI), trigeminal } \\
\text { neuralgia }\end{array}$ & $\begin{array}{l}\text { SS } \\
(r)\end{array}$ & $\begin{array}{l}\text { Cavernous sinus } \\
\text { thrombosis ICA, } \\
\text { cerebral fungal } \\
\text { infection }\end{array}$ & Zygo & Rhizomucor & $\begin{array}{l}\text { L-AmB } \\
(74 \mathrm{~d}) \\
\text { ISC } \\
(12 \mathrm{~m})\end{array}$ & $25 \mathrm{~m}$ \\
\hline $\begin{array}{l}2 \\
F, 56\end{array}$ & $\begin{array}{l}\text { Myelodysplastic } \\
\text { syndrome } \\
\text { Neutropenia }\end{array}$ & Facial pain proptosis & $\begin{array}{c}\text { MS } \\
(r)\end{array}$ & - & Asper & Asp. fumigatus & $\begin{array}{l}\text { Vorico } \\
(12 \mathrm{~m})\end{array}$ & $23 \mathrm{~m}$ \\
\hline $\begin{array}{l}3 \\
F, 53\end{array}$ & $\begin{array}{l}\text { Non-Hodgkin } \\
\text { lymphoma } \\
\text { Neutropenia }\end{array}$ & $\begin{array}{c}\text { Diplopia, headache, } \\
\text { proptosis, cranial } \\
\text { nerve palsy }(\mathrm{VI})\end{array}$ & $\begin{array}{l}\text { SS } \\
(r)\end{array}$ & $\begin{array}{l}\text { Cavernous sinus, } \\
\text { VI cranial nerve, } \\
\text { thrombosis ICA }\end{array}$ & Zygo & Neg. & $\begin{array}{l}\text { L-AmB } \\
(15 \mathrm{~d}) \\
\text { ISC } \\
(9 \mathrm{~m})\end{array}$ & $13 \mathrm{~m}$ \\
\hline $\begin{array}{l}4 \\
M, 76\end{array}$ & $\begin{array}{l}\text { Diabetes mellitus } \\
\text { Debilitated }\end{array}$ & $\begin{array}{l}\text { Headache amaurosis } \\
\text { bilateral }\end{array}$ & $\begin{array}{l}\text { SS } \\
\text { (b) }\end{array}$ & $\begin{array}{c}\text { Cavernous sinus, } \\
\text { intracranial } \\
\text { involvement, Optic } \\
\text { nerve, Orbit }\end{array}$ & Zygo & Asp. fumigatus & $\begin{array}{l}\text { L-AmB } \\
(3 \mathrm{~d})\end{array}$ & $2 d / D$ \\
\hline
\end{tabular}

AIFRS: acute invasive fungal rhinosinusitis; CHT: chemotherapy; MS: maxillary sinus; SS: sphenoid sinus; $b$ : bilateral; I: left; r: right; Asper: Aspergillus; Zygo: Zygomycetes; L-AmB: Liposomal-Amphotericin B; ICA: internal carotid artery; ISC: Isavuconazole; Vorico: Voriconazole; Posa: Posaconazole; m: months; d:days; F/U: follow-up; D: dead; d: day. 
Table II. Clinical and radiological features of the 13 patients with chronic IFRS.

\begin{tabular}{|c|c|c|c|c|c|c|c|c|}
\hline $\begin{array}{l}\text { ID } \\
\text { sex, } \\
\text { age }\end{array}$ & $\begin{array}{l}\text { Underlying } \\
\text { diseases }\end{array}$ & $\begin{array}{l}\text { Presenting symptoms } \\
\text { and signs }\end{array}$ & $\begin{array}{l}\text { Sinuses } \\
\text { involved }\end{array}$ & $\begin{array}{c}\text { Extra } \\
\text { sinonasal sites }\end{array}$ & $\begin{array}{l}\text { Fungal } \\
\text { species }\end{array}$ & Microbiologic & $\begin{array}{l}\text { Antifungal } \\
\text { therapy }\end{array}$ & $F / U$ \\
\hline $\begin{array}{l}1 \\
F, 52\end{array}$ & $\begin{array}{l}\text { Acute myeloid } \\
\text { leukaemia } \\
\text { Neutropenia }\end{array}$ & Facial pain & $\begin{array}{l}\text { MS } \\
\text { (b) }\end{array}$ & - & Zygo & Neg. & $\begin{array}{l}\text { Vorico } \\
(1 \mathrm{~m})\end{array}$ & $52 \mathrm{~m}$ \\
\hline $\begin{array}{l}2 \\
M\end{array}, 65$ & Diabetes mellitus & Headache & $\begin{array}{l}\text { SS } \\
(1)\end{array}$ & - & Asper & Penicillium & $\begin{array}{r}\text { Vorico } \\
(2 \mathrm{~m})\end{array}$ & $49 m$ \\
\hline $\begin{array}{l}3 \\
F, 31\end{array}$ & $\begin{array}{c}\text { Alveolar } \\
\text { rhabdomyosarcoma } \\
\text { CHT+RT. N }\end{array}$ & Facial pain & $\begin{array}{c}\text { MS } \\
(1)\end{array}$ & - & Asper & Neg. & $\begin{array}{r}\text { Vorico } \\
(2 \mathrm{~m})\end{array}$ & $44 \mathrm{~m}$ \\
\hline $\begin{array}{l}4 \\
F, 43\end{array}$ & Diabetes mellitus & $\begin{array}{l}\text { Headache } \\
\text { Facial pain }\end{array}$ & $S S+M S(r)$ & - & Asper & Asp. fumigatus & $\begin{array}{l}\text { Vorico } \\
(2 \mathrm{~m})\end{array}$ & $40 \mathrm{~m}$ \\
\hline $\begin{array}{l}5 \\
M, 47\end{array}$ & - & Facial pain & $\begin{array}{l}\text { MS } \\
(r)\end{array}$ & - & Asper & Asp. fumigatus & $\begin{array}{l}\text { Vorico } \\
(1 \mathrm{~m})\end{array}$ & $33 \mathrm{~m}$ \\
\hline $\begin{array}{l}6 \\
M, 47\end{array}$ & Diabetes mellitus & Facial pain & $\begin{array}{c}\text { MS } \\
(I)\end{array}$ & - & Asper & Asp. fumigatus & $\begin{array}{l}\text { Vorico } \\
(3 \mathrm{~m})\end{array}$ & $29 \mathrm{~m}$ \\
\hline $\begin{array}{l}7 \\
M, 82\end{array}$ & Steroid therapy & $\begin{array}{l}\text { Headache, facial pain, } \\
\text { diplopia }\end{array}$ & $\begin{array}{l}\text { SS } \\
(r)\end{array}$ & $\begin{array}{l}\text { Cavernous sinus, } \\
\text { intracranial } \\
\text { involvement V3, } \\
\text { Orbit }\end{array}$ & Asper & Neg. & $\begin{array}{l}\text { Vorico } \\
(12 \mathrm{~m})\end{array}$ & $16 \mathrm{~m} / \mathrm{D}$ \\
\hline $\begin{array}{l}8 \\
\mathrm{M}, 77\end{array}$ & - & Facial pain & $\begin{array}{c}\text { MS } \\
(I)\end{array}$ & - & Asper & Neg. & $\begin{array}{l}\text { Vorico } \\
(1 \mathrm{~m})\end{array}$ & $14 \mathrm{~m}$ \\
\hline $\begin{array}{l}9 \\
F, 59\end{array}$ & Diabetes mellitus & Facial pain & $\begin{array}{c}\text { MS } \\
(1)\end{array}$ & - & Asper & Neg. & $\begin{array}{l}\text { Vorico } \\
\text { (20 d) }\end{array}$ & $14 \mathrm{~m}$ \\
\hline $\begin{array}{l}10 \\
F, 53\end{array}$ & Rheumatoid arthritis & $\begin{array}{l}\text { Headache } \\
\text { facial pain }\end{array}$ & $\begin{array}{l}\text { SS } \\
\text { (b) }\end{array}$ & - & Asper & Neg. & $\begin{array}{r}\text { Vorico } \\
(3 \mathrm{~m})\end{array}$ & $13 \mathrm{~m}$ \\
\hline $\begin{array}{l}11 \\
M, 68\end{array}$ & Diabetes mellitus & Facial pain & $\begin{array}{r}\text { MS } \\
(r)\end{array}$ & - & Asper & Neg. & $\begin{array}{r}\text { Vorico } \\
(3 \mathrm{~m})\end{array}$ & $12 \mathrm{~m}$ \\
\hline $\begin{array}{l}12 \\
F, 79\end{array}$ & Diabetes mellitus & $\begin{array}{l}\text { Headache } \\
\text { Facial pain } \\
\text { Proptosis, diplopia }\end{array}$ & $\begin{array}{l}\text { SS } \\
(I)\end{array}$ & Cavernous sinus & Asper & Asp. fumigatus & $\begin{array}{l}\text { L-AmB } \\
(1 \mathrm{~m}), \text { Posa } \\
(2 \mathrm{~m})\end{array}$ & $8 \mathrm{~m}$ \\
\hline $\begin{array}{l}13 \\
M, 79\end{array}$ & - & Headache & $\begin{array}{c}\text { SS } \\
(l)\end{array}$ & - & Asper & Asp. fumigatus & Vorico (3m) & $4 \mathrm{~m}$ \\
\hline
\end{tabular}

Table III. Radiologic characteristics of IFRS in non-contrast CT scan.

\begin{tabular}{lccc} 
Sinus involved & Calcification & Bony sclerosis & Bone erosion \\
MS & $10(58.8)$ & $3(17.6)$ & $3(17.6)$ \\
SS & $5(29.4)$ & $6(35.3)$ & $4(23.5)$ \\
Total & $15 / 17$ & $9 / 17$ & $7 / 17$ \\
$\mathrm{n}(\%)$ & $(88.2 \%)$ & $(52.9 \%)$ & $(41.1 \%)$ \\
\hline
\end{tabular}

IFRS: invasive fungal rhinosinusitis; MS: maxillary sinus; SS: sphenoid sinus.

with the chronic indolent form, the delay to surgery in $1 \mathrm{pa}-$ tient (\#13) was linked to the onset of concomitant diseases which required further investigations by other specialists and, consequently, postponed the anaesthesiologic eligibility for surgery.

Bilateral nasal packing was performed in each patient and was removed 48 hours after surgery. No intraoperative complications occurred (Figs. 1-3).
Histological examination confirmed the invasive fungal disease in all cases: Aspergillus was detected in 13 patients (76.47\%) (1 patient in the AIFRS group and 12 patients in the group with the chronic form), and Zygomycetes was detected in 4 patients $(23.52 \%)$ : the intraoperative view showed typical friable cheesy-like yellow to brown material in sinus cavities, confirming the fungal aetiology of the disease already diagnosed macroscopically. 
Table IV. Radiologic findings of IFRS in MRI.

\begin{tabular}{lcccccccc}
$\begin{array}{l}\text { Sinus } \\
\text { involved }\end{array}$ & $\begin{array}{c}\text { T1WI } \\
\text { isol } \\
\text { hypointense }\end{array}$ & $\begin{array}{c}\text { T2 WI markedly } \\
\text { hypointense }\end{array}$ & $\begin{array}{c}\text { Peripheral } \\
\text { enhancement }\end{array}$ & $\begin{array}{c}\text { Cavernous } \\
\text { sinus }\end{array}$ & $\begin{array}{c}\text { Extra-sinonasal involvement } \\
\text { Intracranial }\end{array}$ & $\begin{array}{c}\text { Perineural } \\
\text { spread }\end{array}$ & Orbital & Thrombosis ICA \\
MS & $7(41.1)$ & $7(41.1)$ & $2(11.7)$ & - & - & - & - & - \\
SS & $9(52.9)$ & $9(52.9)$ & $3(17.7)$ & $5(29.4)$ & $2(11.7)$ & 4 & $2(11.7)$ & $2(11.7)$ \\
Total & $16 / 17$ & $16 / 17(94 \%)$ & $5 / 17$ & $5 / 17(29.4 \%)$ & $2 / 17$ & $4 / 17$ & $2 / 17$ & $2 / 17$ \\
$\mathrm{n}(\%)$ & $(94 \%)$ & & $(29.4 \%)$ & & $(11.7 \%)$ & $(23.5 \%)$ & $(11.7 \%)$ & $(11.7 \%)$ \\
\hline
\end{tabular}

IFRS: invasive fungal rhinosinusitis; MS: maxillary sinus; SS: sphenoid sinus; ICA: internal carotid artery.

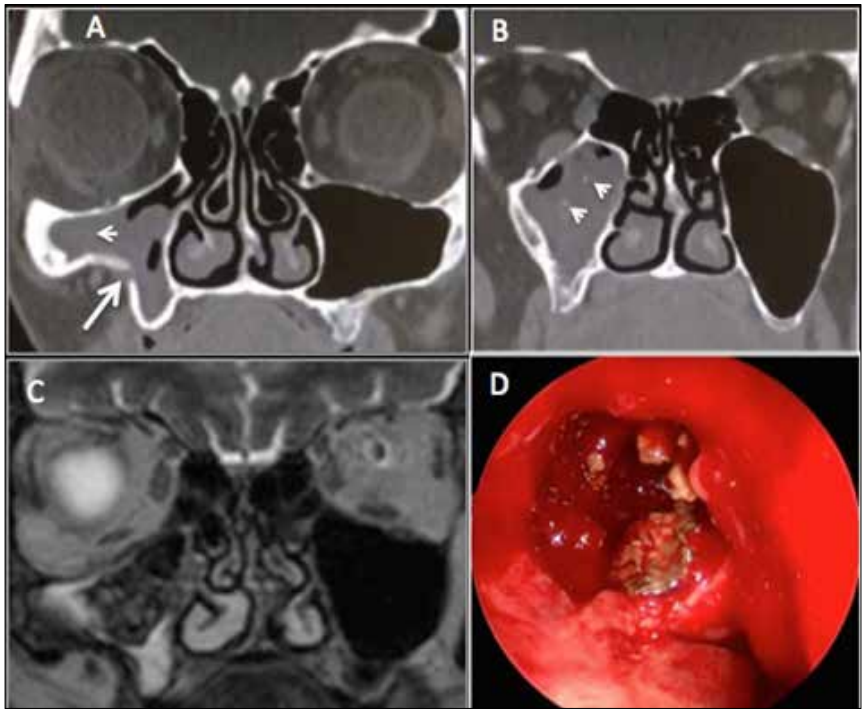

Figure 1. Patient \#2 in the AIFRS group - (A, B) Coronal CT scan shows an opacity of the right maxillary sinus (MS) with associated multiple foci of microcalcifications (white arrowhead) and sclerosis of the MS walls by reactive osteitis. Focal interruption (white arrow) of the lateral wall is also present. (C) Coronal T2-MRI shows marked hypointense signal with areas of hyperintense signal in the lateral and inferior recess of the MS. (D) Intraoperative view showing typical friable cheesy-like yellow to brown material on the floor of the maxillary sinus.

Microbiological analysis was also performed: Aspergillus fumigatus was isolated in 7 patients (41.17\%), Rhizomисо in $1(5.88 \%)$, and Penicillium in 1 case (5.88\%). The causative microorganism could not be determined in 8 patients $(47.05 \%)$.

Bacterial co-infections occurred in 6 patients $(35.29 \%)$ and were most frequently caused by Staphylococcus species and Pseudomonas aeruginosa (11.76\%), followed by one case of Streptococcus pyogenes (5.88\%), one case of Actinomyces $(5.88 \%)$ and one of Haemofilus influenzae (5.88\%). All patients promptly started systemic antimycotic treatment. Voriconazole was administered to 13 patients (76.47\%); the $200 \mathrm{mg}$ bid intravenous formulation was preferred initially and was switched to an oral formu-

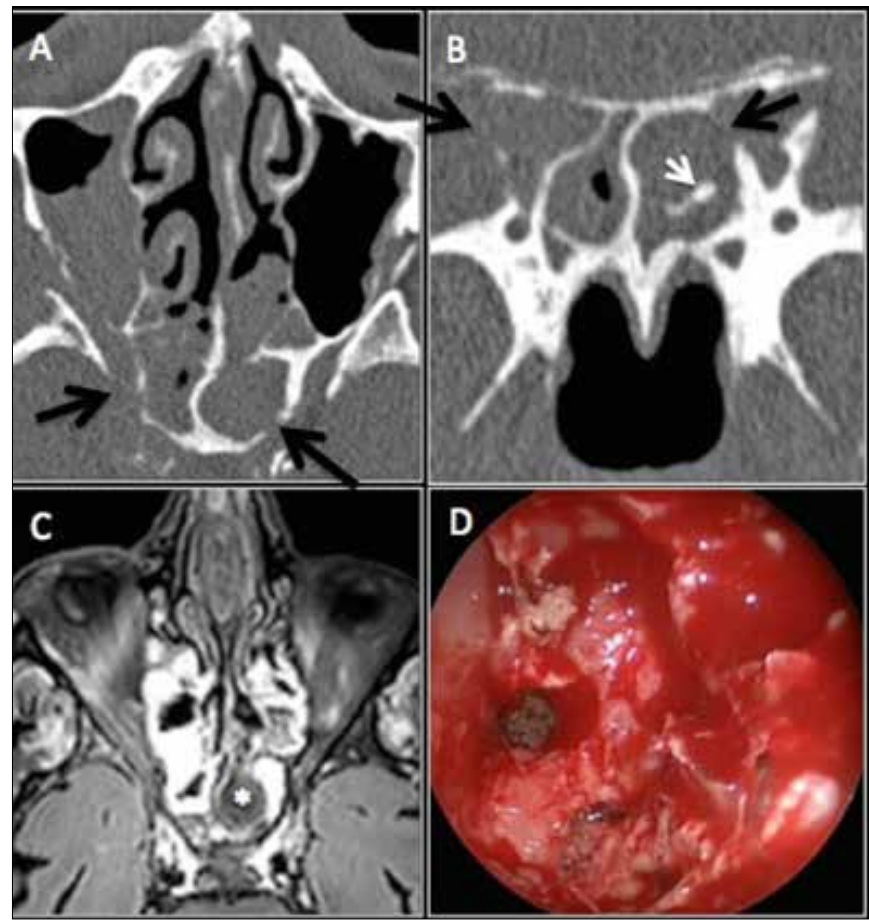

Figura 2. Patient \#4 in the AIFRS group - Axial (A) and coronal (B) CT scans display heterogeneous opacity of the sphenoid sinuses (SS) with associated microcalcification (white arrowhead), thickening and sclerosis of the bone surrounding the SS, and multiple interruptions of its bony wall (black arrow). (C) Axial gadolinium-enhanced T1-weighted MRI demonstrates a marked hypointense signal (asterisk) in the left SS with inflamed mucosa at the periphery. (D) Endoscopic removal of fungal concretion after opening the anterior wall of the left SS.

lation when possible, on average after a period of 3.41 months (range $=20$ days- 12 months, median $=2$ months, IQR $=2)$; 4 patients $(23.52 \%)$ were treated with liposomal amphotericin B $(\mathrm{L}-\mathrm{AmB})$ (range $=3$ days-12 months, median $=0.74$ months, $\mathrm{IQR}=1.88)$ with dosages from 3 to $10 \mathrm{mg} / \mathrm{kg} / \mathrm{day}$; in 3 selected cases, isavuconazole with a dosage of $200 \mathrm{mg} /$ day in intravenous or oral formulation or posaconazole at $300 \mathrm{mg} /$ day were also used in association. In total, 15 patients are still in follow-up with a mean 


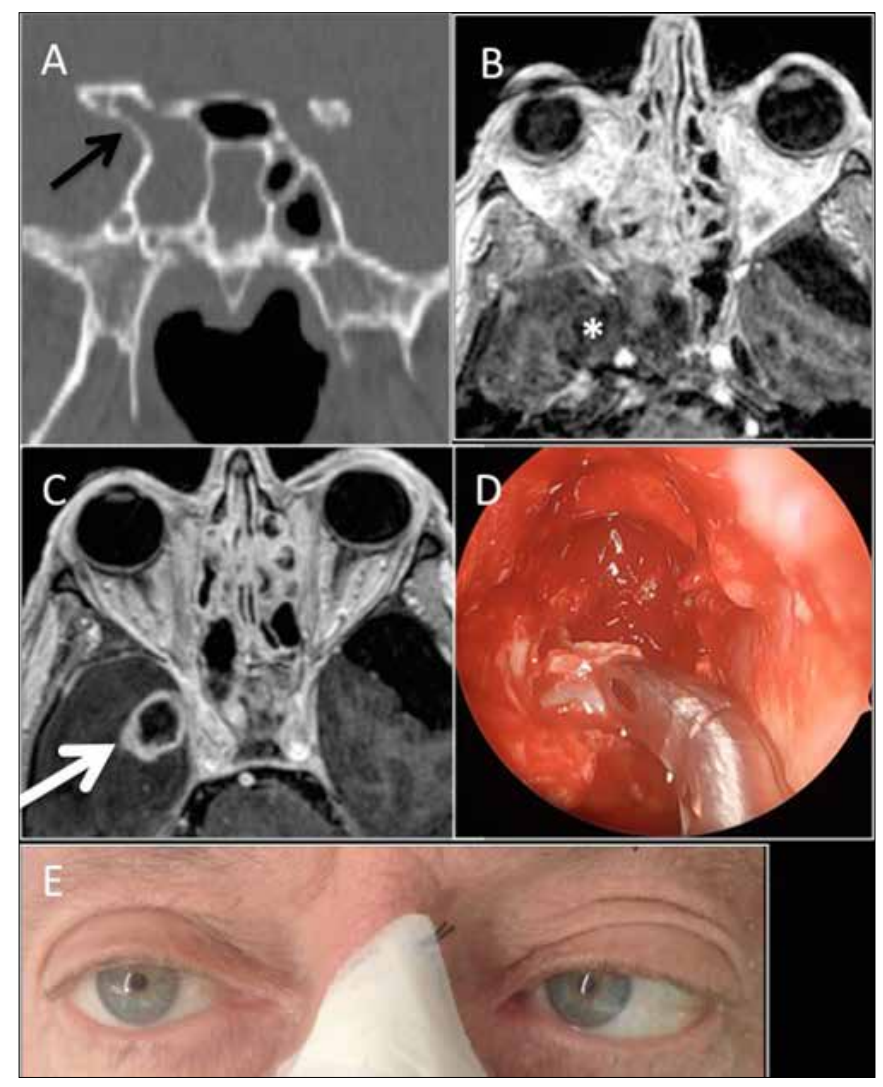

Figura 3. Patient \#1 in the AIFRS group - (A) Coronal CT scan showing complete opacification of the right sphenoid sinus with optical right nerve canal wall erosion (black arrows). (B) Axial MRI with contrast shows a hypointense signal in a large space-occupying lesion in the right SS extending into the right cavernous sinus (asterisk). The cavernous carotid artery appears unobstructed. (C) Endocranial mycotic abscess (white arrow) with inflamed mucosa within Meckel's cave on the right at periphery at day 41. (D) Intraoperative view during endoscopic sinus surgery in the right SS. (E) Absence of motility of the right eye in lateral gaze related to the deficit of the right lateral rectus muscle for abducens nerve palsy.

duration of 20.12 months (range $=0.06-58$ months; median $=16$ months, IQR = 24), 2 patients died $(11.76 \%), 1$ patient from cerebral ischaemia and the other from uncontrolled rhinocerebral infection.

Only one relapse was observed with persistence of fungal pathology in the sphenoidal sinus, requiring revision surgery at 6 months and with a histological diagnosis of $A s-$ pergillus.

\section{Discussion}

A diagnosis of IFRS requires histopathologic evidence of fungi invading nasal tissue, characterised by a dense accumulation of hyphae, the occasional presence of vascular invasion and a diffuse inflammatory reaction ${ }^{12}$.

Acute IFRS is characterised by a rapid evolution and is associated with a high mortality rate that can reach $100 \%$ in cases of intracranial mycotic dissemination: Zygomycetes (Rhizopus, Mucor, Rhizomucor) and species of Aspergillus are the most common aetiologic agents in the sinonasal cavity, with more frequent neurovascular and orbital invasion ${ }^{13}$. CT scans show homogeneous opacification of the sinus with calcification, adjacent bone erosion, dehiscence of the lateral sphenoid's recess with signs of remodeling in the wall of the sphenoid sinus, especially in immunocompromised patients ${ }^{14}$. Signal intensity was evaluated using MRI, and was grouped into three categories: slightly T1weighted iso- or hypointense, markedly $\mathrm{T} 2$-weighted hypointense (near signal void), and peripheral enhancement of the surrounding mucosa. On MRI, orbital and intracranial involvement were present as suggested findings, together with perineural spread and expansion outside the confines of the sinonasal cavity with cavernous sinus involvement or thrombosis of the ICA, and have been reported previously ${ }^{15}$.

Clinical suspicion of AIFRS should be raised in the immunocompromised patient presenting with new-onset, rapidly progressive sinusitis or facial discomfort ${ }^{16}$.

In our experience, symptomatology in AIFRS patients was very evident when a sphenoidal localisation was present (proptosis, diplopia, cranial nerve palsy (VI), trigeminal neuralgia, or visual abnormalities) because of a connection between the sphenoidal sinus and anatomic structures such as the ICA, cavernous sinus, optic nerve, eyehole, or brain ${ }^{17}$. Therefore, thanks to the rapidity of onset, patients with AIFRS came immediately to our clinic, and we performed an emergency surgical intervention thereby preventing serious cerebral and ocular complications. On the other hand, patients with the chronic indolent form showed nonspecific and slowly progressive signs and symptoms that did not arouse suspicion in the patient, delaying access to the emergency room and consequently, to the diagnostic and therapeutic process.

As reported in a review of over 800 patients by Turner et al., Aspergillus spp. and Mucor spp. can both be found in neutropenic patients and in those with chronic systemic steroid treatment, whereas Mucor spp. has a propensity for diabetic and iron-overloaded patients ${ }^{18}$.

Neutropenia plays a key role as a factor contributing to the development of infection in patients with haematological disease. In the present study, $29.41 \%$ of patients were affected by a severe neutropenic state, defined as a neutrophil count $<500 / \mathrm{mmc}^{19}$, and $23.52 \%$ of patients had an underlying haematological disease, such as non-Hodgkin lymphoma, myelodysplastic syndrome or acute myeloid leukemia. Other underlying conditions included poorly controlled DM, immunosuppressive treatment and corticosteroid exposure ${ }^{20}$. 
Our data show a significant proportion of patients infected by Aspergillus fumigatus in the chronic indolent group $(92.30 \%)$ and only one patient was affected (pt\#1) by Zygomycetes $(7.70 \%)$. Conversely, in AIFRS patients, Zygomycetes were the fungi mainly responsible for the infection and only in one patient (\#2) was Aspergillus fumigatus isolated.

In line with the results obtained in our previous study ${ }^{21}$, it is still unclear why the microbiological evidence for fungal disease was negative in 8 cases, although the radiologic and endoscopic intraoperative findings were strongly indicative of IFRS.

Treatment for both groups was based on a combination of antifungal therapy, reversal of immunocompromising factors, surgical debridement through ESS when possible and obtaining material for histopathological and cultural examinations ${ }^{22}$.

Vaughan et al. analysed 37 mucormycosis cases and found no significant difference in survival between patients having surgery 1-30 days after diagnosis ${ }^{23}$. These data agree with our study, with an onset of treatment on average 32.41 days after diagnosis, highlighting why the start of treatment should be initiated as soon as IFRS is diagnosed.

For an early surgical approach, the correct medical therapy must be promptly selected based on the fungal pathogen affecting the patient: we can generalise that the current mainstay of therapy for IFRS is L-AmB (recommended dosage from 3 to $10 \mathrm{mg} / \mathrm{kg}$ per day) ${ }^{24}$. For invasive aspergillosis, treatment with voriconazole is recommended primarily for patients with cranial nerve involvement. Alternatively, isavuconazole, a second generation triazole, has been shown to be as effective as voriconazole and better tolerated. For mucormycosis IFRS treatment, L-AmB and posaconazole are the most recommended drugs, together with isavuconazole which can be administered in patients in whom amphotericin B cannot be administered because of intolerance or in the case of kidney disease. Combination therapy with two drugs has been reported. In the current study, $76.47 \%$ of our patients were treated with voriconazole, showing fewer systemic side effects than L$\mathrm{AmB}$, a favourable bone penetration and good tolerance as maintenance therapy.

Isavuconazole is an innovative and effective therapeutic option with a very high oral bioavailability (98\%), a good profile of tolerability and efficacy and a low risk of interactions with other drugs ${ }^{25}$. However, further studies are needed to better integrate isavuconazole in the management of patients with IFRS, with the aim to define a clear correlation between plasma levels and efficacy end points and to identify the best therapeutic window in which to administer it.
Due to the relative rarity of AIFRS, our data was limited to acute and chronic indolent IFRS, and unfortunately did not include granulomatous forms, thus precluding larger cohort studies. The results are dependent on the quality of the limited data available, but are in line with the current literature. Moreover, our study focused on differentiating acute and chronic indolent forms, which was not always easy to recognise with certainty in previous studies, so as to guide the most appropriate diagnostic and therapeutic process.

\section{Conclusions}

Invasive fungal rhinosinusitis is a difficult infection to diagnose and treat. Early diagnosis is the key to managing IFRS successfully, and with a systematic approach, it is possible to improve survival, taking into account the context of the temporal course of the diagnostic work-up and treatment. The goal is diagnosis of the disease at an earlier stage while it is confined to the sinonasal cavities before mucosal dissemination. A multidisciplinary approach consisting of antifungal therapy, surgical debridement, and reversal of predisposing conditions is the best therapy to improve survival.

\section{References}

1 Ergun O, Tahir E, Kuscu CO, et al. Acute invasive fungal rhinosinusitis: Presentation of 19 cases, review of the literature and a new classification system. J Oral Maxillofac Surg 2016;75:767.e1-e9. https:// doi.org/10.1016/j.joms.2016.11.004

2 Montone KT. Pathology of fungal rhinosinusitis: a review. Head Neck Pathol 2016;10:40-6. https://doi.org/10.1007/s12105-016-0690-0

3 Deutsch PG, Whittaker J, Prasad S. Invasive and non-invasive fungal rhinosinusitis - a review and update of the evidence. Medicina (Kaunas) 2019;55:319. https://doi.org/10.3390/medicina55070319

4 Trief D, Gray ST, Jakobie C, et al. Invasive fungal disease of the sinus and orbit: a comparison between mucormycosis and Aspergillus. J Ophthalmol 2016;100:184-8. https://doi.org/10.1136/bjophthalmol-2015-306945

5 Duggal P, Wise SK. Invasive fungal rhinosinusitis. Am J Rhinol Allergy 2013;27(Suppl 1):S28-30. https://doi.org/10.2500/ajra.2013.27.3892

6 Zuniga MG, Turner JK. Treatment outcomes in acute invasive fungal rhinosinusitis. Curr Opin Otolaryngol Head Neck Surg 2014;22:2428. https://doi.org/10.1097/MOO.0000000000000048

7 Shanbag R, Rajan NR, Kumar A. Acute invasive fungal rhinosinusitis: our 2-year experience and outcome analysis. Eur Arch Otorhinolaryngol 2019;276:1081-7. https://doi.org/10.1007/s00405-019-05288-w

8 Chang C, Gershwin ME, Thompson III GR. Fungal disease of the nose and sinuses: an updated overview. Curr Allergy Asthma Rep 2013;13:152-61. https://doi.org/10.1007/s11882-012-0320-1

9 Kovanda LL, Marty FM, Maertens J, et al. Impact of mucositis on absorption and systemic drug exposure of isavuconazole. Antimicrob Agents Chemother 2017;61:e00101-17. https://doi.org/10.1128/ AAC.00101 17.2017

10 Thompson GR, Patterson TF. Fungal disease of the nose and paranasal sinuses. J Allergy Clin Immunol 2012;129:321-6. https://doi. org/10.1016/j.jaci.2011.11.039 
11 Bölük G, Kazak E, Özkalemkaş F, et al. Comparison of galactomannan, beta-D-glucan, and Aspergillus DNA in sera of high-risk adult patients with hematological malignancies for the diagnosis of invasive aspergillosis. Turk J Med Sci 2016;46:335-42.

12 Pagella F, Matti E, De Bernardi F, et al. Paranasal sinus fungus ball: diagnosis and management. Mycoses 2007;50:451-6. https://doi. org/10.1111/j.1439-0507.2007.01416.x

13 Craig JR. Updates in management of acute invasive fungal rhinosinusitis. Curr Opin Otolaryngol Head Neck Surg 2019;27:29-36. https://doi.org/10.1097/MOO.0000000000000507

14 Groppo ER, El-Sayed IH, Aiken AH, et al. Computed tomography and magnetic resonance imaging characteristics of acute invasive fungal sinusitis. Arch Otolaryngol Head Neck Surg 2011;137:1005-10. https://doi.org/10.1001/archoto.2011.170

15 Mossa-Basha M, Ilica AT, Maluf F, et al. The many faces of fungal disease of the paranasal sinuses: CT and MRI findings. Diagn Interv Radiol 2013;19:195-200. https://doi.org/10.5152/dir.2012.003

16 Silveira MLC, Anselmo-Lima WT, Faria FM, et al. Impact of early detection of acute invasive fungal rhinosinusitis in immunocompromised patients. BMC Infect Dis 2019;19:310. https://doi.org/10.1186/ s12879-019-3938-y

17 Fadda GL, D'Eramo A, Grosso A, et al. Isolated sphenoid sinus inflammatory disease - a report of 14 cases. Iran J Otorhinolaryngol 2020;32:101-7. https://doi.org/10.22038/ijorl.2019.39416.2304

18 Turner JH, Soudry E, Nayak JV, et al. Survival outcomes in acute invasive fungal sinusitis: a systematic review and quantitative synthesis of published evidence. Laryngoscope 2013;123:1112-8. https://doi. org/10.1002/lary.23912

19 Zappasodi P, Rossi M, Castagnola C, et al. Resolution of invasive fun- gal sinusitis in immunocompromised patients: neutrophil count is crucial beside a combined medical and surgical approach. Ann Hematol 2010;89:737-9. https://doi.org/10.1007/s00277-009-0854-z

20 Di Girolamo S, Mazzone S, Di Mauro R, et al. Surgical management of rhinosinusitis in onco-hematological patients. Clin Exp Otorhinolaryngol 2014;7:302-6. https://doi.org/10.3342/ceo.2014.7.4.302

21 Fadda GL, Succo G, Moretto P, et al. Endoscopic endonasal surgery for sinus fungus balls: clinical, radiological, histopathological, and microbiological analysis of 40 cases and review of the literature. Iran J Otorhinolaryngol 2019;31:35-44.

22 Fadda GL, D'Eramo A, Gned D, et al. An unusual case of complicated rhinosinusitis of the sphenoid sinus involving the cavernous sinus and skull base: endoscopic sinus surgery and medical therapy. SAGE Open Med Case Rep 2019 May 26;7:2050313X19852885. https://doi. org/10.1177/2050313X19852885

23 Vaughan C, Bartolo A, Vallabh A, et al. A meta-analysis of survival factors in rhino-orbital-cerebral mucormycosis - has anything changed in the past 20 years. Clin Otolaryngol 2018;43:1454-64. https://doi.org/10.1111/coa.13175

24 Debbarma S, Gupta R, Patro SK, et al. Randomised comparison of safety profile and short-term response of itraconazole, voriconazole and amphotericin $\mathrm{b}$ in the management of chronic invasive fungal rhinosinusitis. Indian J Otolaryngol Head Neck Surg 2019;71(Suppl 3):2165-75. https://doi.org/10.1007/s12070-019-01602-4

25 Andreani G, Fadda GL, Gned D, et al. Rhino-orbital-cerebral mucormycosis after allogeneic hematopoietic stem cell transplantation and isavuconazole therapeutic drug monitoring during intestinal graft versus host disease. Mediterr J Hematol Infect Dis 2019;11:e2019061. https://doi.org/10.4084/MJHID.2019.06 